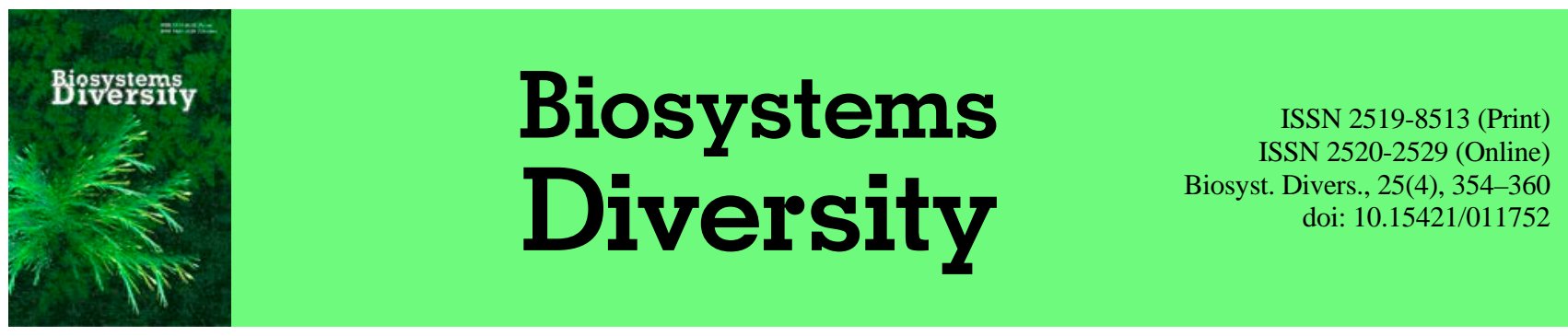

\title{
Species-specific morphological characteristics of adult and embryonic Capillaria obsignata roundworms (Nematoda, Capillariidae)
}

\author{
V. A. Yevstafyeva*, V. V. Stybel**, T. A. Sharavara*, V. V. Melnychuk*, \\ I. O. Yasnolob*, A. A. Antipov***, V. P. Goncharenko***, T. I. Bakhur*** \\ *Poltava State Agrarian Academy, Poltava, Ukraine \\ **Lviv National University of Veterinary Medicine and Biotechnologies named after S. Z. Gzhytskyj, Lviv, Ukraine \\ ***Bila Tserkva National Agrarian University, Bila Tserkva, Ukraine
}

Article info

Received 12.10.2017

Received in revised form 17.11.2017

Accepted 19.11.2017

Poltava State Agrarian Academy,

Skovorody Str., 1/3,

Poltava, 36003, Ukraine

Tel.:+38-050-183-78-78.

E-mail:evstva@ukr.net

Lviv National University of Veterinary Medicine and Biotechnologies named

after S. Z. Gzhytskyj, Pekarska Str., 50, Lviv, 79000, Ukraine.

E-mail:vstybel@ukr.net

Bila Tserkva National Agrarian University, Soborna Str., 8/1,

Bila Tserkva, 09100, Ukraine.

E-mail: antipov_anatolii@ukr.net

\section{Introduction}

Parasitic nematodes are one of the most numerous and widespread groups of parasitic worms. The suborder Trichurata Skijabin et Schulz, 1928 is an especially prominent group of parasitic roundworms, including capillariid nematodes (Capillariidae NeveuLemaire, 1936). The taxonomy and taxonomy of capillariids are contentious. Different capillariid species parasitize humans, monkeys, wild and domestic carnivores, rodents, fish, reptiles, ruminants, and wild and domestic poultry. The results of morphological studies are of great importance in the consideration of systematics, developmental biology and phylogeny of capillariids (Petrochenko and Kotelnikov, 1976; Lomakin and Romashov, 1987; Moravec et al., 1994; Timi et al., 2006; Moravec and Muzzall, 2009).

The wide distribution of Capillaria obsignata Madsen, 1945 which parasitizes both poultry (Gallus gallus dom., Meleagris gallopavo) and wild birds (Columba livia, Zenaidura carolinensis, Perdix perdix, Phasianus colchicus, Sturnus vulgaris) in areas with varying climatic conditions is confirmed in numerous studies (Wakelin, 1965, 1966; Park and Shin, 2010; Gürler et al., 2012; Pasechnik, 2013).

This adaptation to parasitizing different avian species in various geoclimatic regions, and its prevalence over other capillariid species are sustained by this roundworm's life cycle. It does not require an intermediate host, allowing fast distribution and adaptation of C. obsignata, especially among chickens. This species was found at poultry farms in Africa (Mukaratirwa et al., 2001; Mukaratirwa and
Khumalo, 2010), Vietnam (Schou et al., 2007), Morocco (Hassouni and Belghyti, 2006), Germany (Kaufmann et al., 2011), and USA (Yazwinski et al., 2013). The ratio of infected chickens ranged from $0.3 \%$ to $75.3 \%$, and the intensity of infection was up to 1280 nematodes.

Many researchers point out the morphological taxonomic characters of $C$. obsignata and other avian capillariid species, such as: posterior end of male, spicule, ornamentation of spicule sheath, the shape and number of stichocytes (large glandular cells along the posterior part of the esophagus), and the shape and size of eggs, and the vulva area in females (Paramonov, 1957; Gagarin, 1971; Tanveer et al., 2013). Lately it has been proposed to consider capillariid morphometry characteristics, since several species are difficult to identify because of their morphological similarity both in males and females. The reviewed characters are the length and width of body, the anterior to posterior body portions length ratio, in males - the length and width of spicule and in females the distance between the esophagus end and the vulva, body width at the vulva area, and the distance between the anus and posterior end (Kajerová and Baruš, 2005; D’ávila et al., 2012, 2017). Also, studies indicate that the shape, size and the ornamentation of the egg's outer surface are species-specific characters for the family Capillariidae. They are divided by the shape into three major groups: elongated (oblong, cylindrical), oval (rounder, barrel-shaped), and round (lemonshaped) (Nasirov, 1981; Romashov, 1985).

There is still a lot of confusion regarding the systematic placing and the species composition of avian capillariasis pathogens. For 
example, Capillaria obsignata is also referred to as Baruscapillaria columbae, Baruscapillaria obsignata, and Capillaria columbae (Levine, 1938; Wehr, 1939; Tamaru et al., 2015).

Lacking a system of well-defined diagnostic tests based on evaluation of qualitative and quantitative morphological characters, it is quite difficult to identify capillariid species. In Ukraine, the prevalence of $C$. obsignata in poultry has been studied but irregularly, and the worm's morphometric characteristics of adult and embryonic stages are insufficiently reviewed.

The purpose of this article was to find out the prevalence of Capillaria obsignata (Madsen, 1945) in chickens (Gallus gallus dom.) in the central region of Ukraine, and also to determine the differential taxonomic characters of adult and embryonic stages of this species, taking into account their biology.

\section{Materials and methods}

The studies were conducted in 2015-2017 at the Laboratory of Parasitology and Veterinary-Sanitary Expertise of the Department of Veterinary Medicine of Poltava State Agrarian Academy, and in the I. I. Schmalhausen Institute of Zoology, National Academy of Sciences of Ukraine. The population structure of $C$. obsignata was studied in poultry farms of Poltava and Kyiv regions. The main indicators were the abundance index and the intensity of infection (Ripolovskyj and Yuskiv, 2010). Helminthes were collected during the complete helminthological dissection of the digestive tract (mouth, crop, esophagus, small intestine and colon) of dead or killed chickens (Skrjabin, 1928). The roundworms were identified according to (Skrjabin, 1957). In total, 1,434 adult specimens of C. obsignata nematodes were studied, 1,273 of them female and 161 male.

To study the morphological and meristic parameters of the roundworms' eggs, they were extracted from various substrates: the female nematode gonads (Eg) and the feces of infected chickens (Ef). The studied characters were the shape, surface, length and width of eggs, egg plug length and width, eggshell thickness, and the areas of the outer and inner egg surfaces.

The embryogenesis of $C$. obsignata was studied in eggs extracted from the feces of infected chickens and cultured to the invasive stage in a thermostat at $25^{\circ} \mathrm{C}$ for 10 to 12 days. Every two days the culture was examined under a microscope. The experiments were conducted in triplicate.

Morphometric parameters of embryonic and adult stages of C. obsignata were analyzed using ImageJ for Windows ${ }^{\circledR}$ (version 2.00 ) in interactive mode using $\times 10$ and $\times 40$ objective, and $\times 10$ photo eyepiece. To calibrate the image analyzer, the ruled scale of an ocular micrometer was calibrated with the scale of stage micrometer included in MikroMed microscope kit. Microphotography was performed using a 5 Mpix digital camera of MikroMed (China) microscope. The material and significance levels were analyzed using standard methods of statistical processing. All the data are reported as the sample mean \pm the standard deviation (SD) (Lapach et al., 2001).

\section{Results}

It was established that $C$. obsignata nematodes are quite common in the central region of Ukraine. The dissection of 425 chickens resulted in 1,434 specimens of $C$. obsignata roundworms, and the intensity of infection ranged from 3 to 317 specimens. The average abundance index of this parasite was 3.4. The females were found much more often $(1,237)$ than males $(161)$, the corresponding ratio is 7.9 to 1.0 . It was also determined that $3.5 \%$ of the studied chickens had only female roundworms, supporting the need for identification characters for female nematodes.

It is found that $C$. obsignata nematodes have several distinguishing morphological parameters which facilitate the species identification. Thus, the capillariid body is filiform both in males and in females, barely visible to the naked eye, translucent, without any distinctive visual signs. This study confirmed the sexual dimorphism in this species (Table 1). The female Capillaria is on average $14.75 \pm 0.82 \mathrm{~mm}, 23.7 \%$ longer than the male $(11.25 \pm 0.63 \mathrm{~mm})$. The females are also wider by $10.2-17.2 \%$ than males. The microscopy study revealed no distinctive morphologic characters of the anterior end in males and females (Fig. 1).

In males, the posterior end structure in the area of the sexual bursa is the typical morphological character of the species. In C. obsignata it is weakly developed as a pseudobursa. The pseudobursa is not large ( $25.45 \pm 1.54 \mu \mathrm{m}$ in length, $35.54 \pm 1.42 \mu \mathrm{m}$ in width), transparent and not lobed, and on each side it has a wide rounded ray, which slightly narrows at the base (Fig. $2 a$ ). The distance between rays is $13.57 \pm 0.74 \mu \mathrm{m}$. A mature $C$. obsignata male has only one spicule, thin and long $(1.62 \pm 0.07 \mathrm{~mm})$ with thin rounded distal end $(5.67 \pm 0.39 \mu \mathrm{m})$ (Fig. $3 a)$, which is 3.8 times thinner than the proximal end $(21.45 \pm 1,72 \mu \mathrm{m})$. The latter has a funnelshaped, $27.15 \pm 0.34 \mu \mathrm{m}$ long dilatation (Fig. $3 b$ ). The spicule is covered by a thin sheath, transversely striated and lacking spikes (Fig. 2b). The average length of the spicule sheath is $2.80 \pm 0.41 \mathrm{~mm}$. It is 1.4 times wider at the proximal end $(23.24 \pm 1.20 \mu \mathrm{m})$ than at the distal end $(16.89 \pm 0.40 \mu \mathrm{m})$.

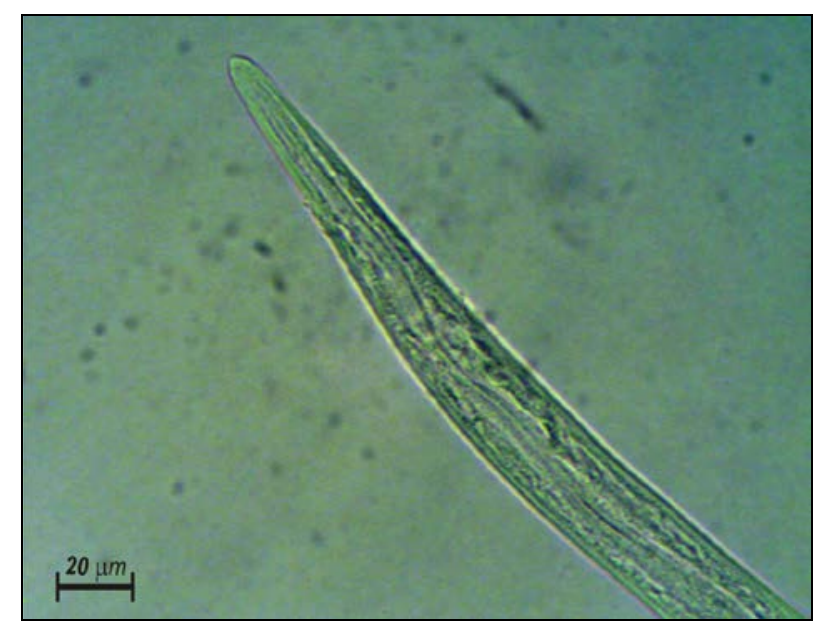

Fig. 1. Anterior end of Capillaria obsignata

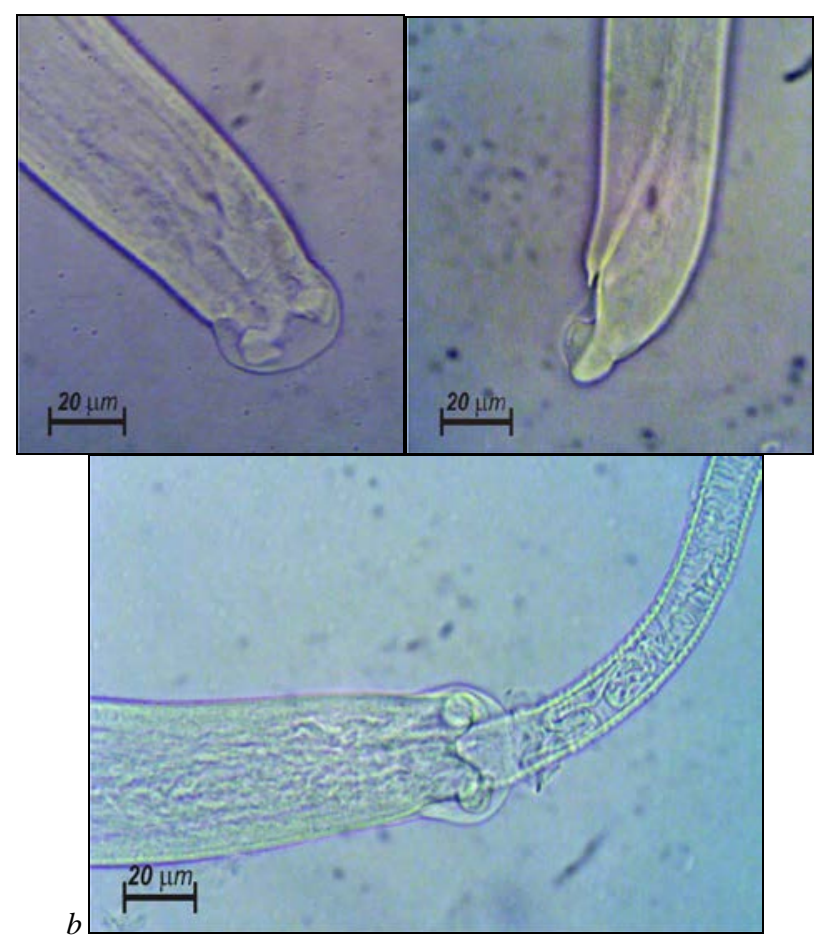

Fig. 2. Posterior end of $\widehat{\partial}$ Capillaria obsignata: $a$-pseudobursa with rays, $b$ - spicule sheath (spicule is extruded) 
A mature $C$. obsignata female has such species-specific morphological characters as vulval area structure and meristic indexes of body in the area of sexual organs. The vulva is a slit with cuticle protrusion in the shape of a genital or vulval lip. The latter is quite unstable in size: its length varies from 22.9 to $29.7 \mu \mathrm{m}$, and its height from 2.0 to $7.2 \mu \mathrm{m}$ (Fig. 4).

Table 1

Morphometric parameters of adult Capillaria obsignata roundworms $(\mathrm{n}=10)$

\begin{tabular}{|c|c|c|c|c|}
\hline \multirow{2}{*}{ Characters } & \multicolumn{2}{|c|}{$\hat{0}$} & \multicolumn{2}{|c|}{ q } \\
\hline & $\mathrm{M} \pm \mathrm{SD}$ & $\min -\max$ & $\mathrm{M} \pm \mathrm{SD}$ & $\min -\max$ \\
\hline Body length, mm & $11.25 \pm 0.63$ & $10.5-12.5$ & $14.75 \pm 0.82$ & $13.5-16.0$ \\
\hline \multicolumn{5}{|l|}{ Body width at: } \\
\hline - anterior end, $\mu \mathrm{m}$ & $8.47 \pm 0.56$ & $7.4-9.4$ & $9.43 \pm 0.53$ & $8.3-10.2$ \\
\hline - esophagus end, $\mu \mathrm{m}$ & $47.27 \pm 1.94$ & $44.1-49.6$ & $57.09 \pm 2.65$ & $52.1-61.3$ \\
\hline - posterior end, $\mu \mathrm{m}$ & $38.48 \pm 1.78$ & $35,2-41,3$ & - & - \\
\hline - vulva, $\mu \mathrm{m}$ & - & - & $55.26 \pm 2.70$ & $50.7-59.1$ \\
\hline - anus, $\mu \mathrm{m}$ & - & - & $34.59 \pm 1.90$ & 31.9-37.3 \\
\hline Distance from esophagus end to vulva, $\mu \mathrm{m}$ & - & - & $82.65 \pm 4.63$ & 76.6-91.3 \\
\hline Length of cuticle protrusion in the vulva area, $\mu \mathrm{m}$ & - & - & $27.39 \pm 2.41$ & $22.9-29.7$ \\
\hline Height of cuticle protrusion in the vulva area, $\mu \mathrm{m}$ & - & - & $4.46 \pm 1.77$ & $2.0-7.2$ \\
\hline Length of vagina, $\mu \mathrm{m}$ & - & - & $173.66 \pm 9.81$ & $160.7-185.6$ \\
\hline Length of spicule, mm & $1.62 \pm 0.07$ & $1.5-1.7$ & - & - \\
\hline Length of funnel-shaped dilatation of spicule, $\mu \mathrm{m}$ & $27.15 \pm 1.06$ & $25.7-28.9$ & - & - \\
\hline \multicolumn{5}{|l|}{ Width of spicule at: } \\
\hline - proximal end, $\mu \mathrm{m}$ & $21.45 \pm 1,72$ & $18.7-24.0$ & - & - \\
\hline - after dilatation, $\mu \mathrm{m}$ & $11.73 \pm 0,94$ & $10.3-13.2$ & - & - \\
\hline - in the middle, $\mu \mathrm{m}$ & $8.93 \pm 0.57$ & 8.2-9.7 & - & - \\
\hline - distal end, $\mu \mathrm{m}$ & $5.67 \pm 0.39$ & $5.1-6.2$ & - & - \\
\hline Length of spicule sheath, mm & $2.80 \pm 0.41$ & $2.2-3.6$ & - & - \\
\hline Width of proximal end of spicule sheath, $\mu \mathrm{m}$ & $23.24 \pm 1.20$ & $21.1-24.5$ & - & - \\
\hline Width of distal end of spicule sheath, $\mu \mathrm{m}$ & $16.89 \pm 0.40$ & $16.0-17.5$ & - & - \\
\hline Length of pseudobursa, $\mu \mathrm{m}$ & $25.45 \pm 1.54$ & 23.6-28.1 & - & - \\
\hline Width of pseudobursa, $\mu \mathrm{m}$ & $35.54 \pm 1.42$ & $33.1-37.5$ & - & - \\
\hline Width of pseudobursal base, $\mu \mathrm{m}$ & $33.70 \pm 2.07$ & $30.2-37.5$ & - & - \\
\hline Distance between pseudobursal rays, $\mu \mathrm{m}$ & $13.57 \pm 0.74$ & $12.3-14.8$ & - & - \\
\hline
\end{tabular}

Note: “_“- parameters were not defined.
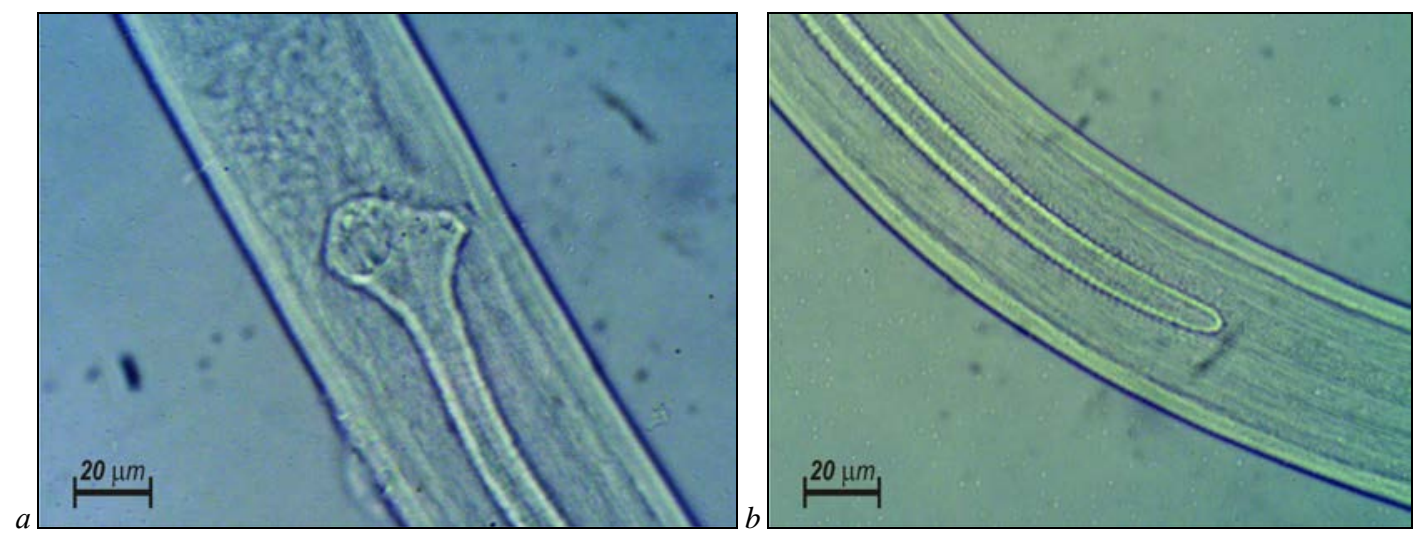

Fig. 3. The spicule of $\hat{\alpha}$ Capillaria obsignata: $a$-proximal end, $b$ - distal end

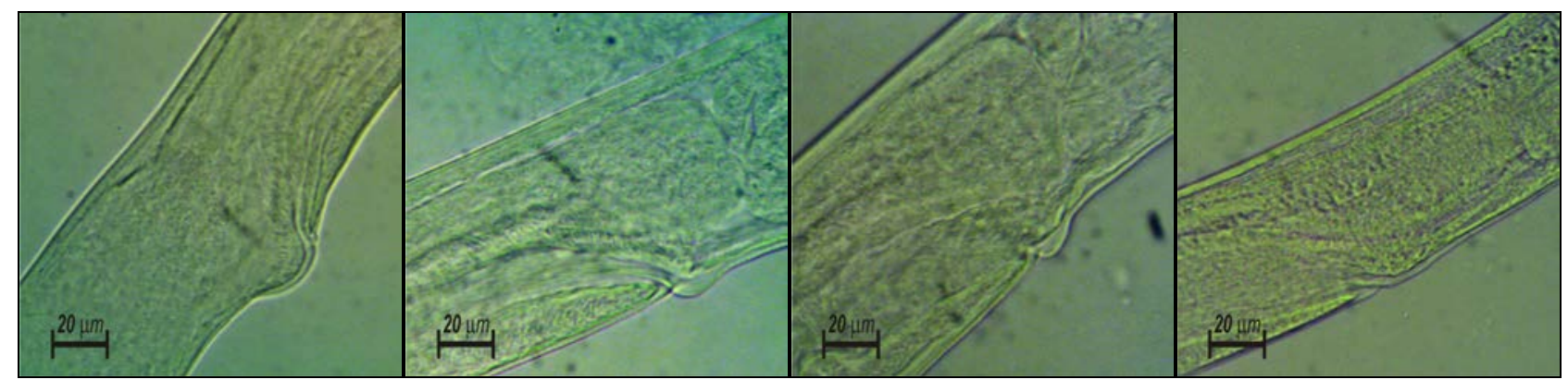

Fig. 4. Vulval area of $q$ Capillaria obsignata: the variability of cuticle lip size

The differential character is the distance between the esophagus end and the vulva, which is $82.65 \pm 4.63 \mu \mathrm{m}$ on average. The vulva is located behind the junction of the esophagus with the intestine. The vagina has a well developed muscular wall and is $173.66 \pm$ $9.81 \mu \mathrm{m}$ long. The uterus is filled with eggs. The tail end of the female is blunt, the anus is subterminal, the body width in this area is $34.59 \pm 1.90 \mu \mathrm{m}$.
The outer structure of C. obsignata eggs is typical for Capillariidae: barrel-shaped, with egg plugs on both ends, of various brown shades. The egg has a thick transparent eggshell and is not mature (Fig. 5). Comparison of $C$. obsignata eggs extracted from different substrates reveals a significant difference by all considered morphometric parameters (Table 2). 


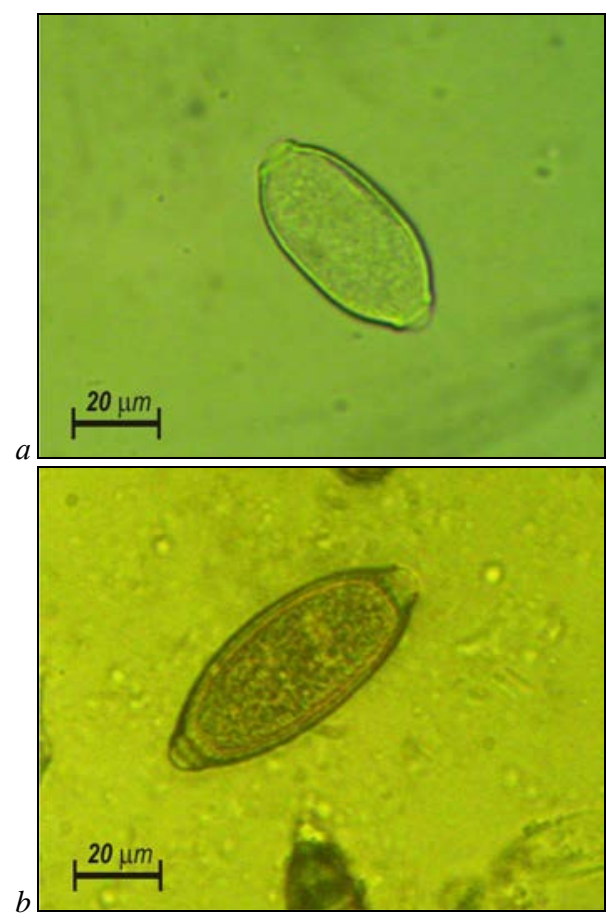

Fig. 5. The eggs of Capillaria obsignata extracted from different substrates: $a$ - from female nematode gonads, $b$ - from feces of infected chickens

Table 2

Meristic parameters of Capillaria obsignata, eggs extracted from different substrates $(n=10)$

\begin{tabular}{lrrrl}
\hline \multicolumn{1}{c}{ Indicators } & & min & max & \multicolumn{1}{c}{$\mathrm{M} \pm \mathrm{SD}$} \\
\hline \multirow{2}{*}{ Total egg length, $\mu \mathrm{m}$} & Eg & 50.5 & 56.2 & $53.1 \pm 2.1$ \\
& Ef & 60.1 & 74.6 & $65.3 \pm 5.1^{* * *}$ \\
\hline Length of egg without & Eg & 45.3 & 49.6 & $47.2 \pm 1.3$ \\
the egg plugs, $\mu \mathrm{m}$ & Ef & 58.3 & 70.1 & $63.0 \pm 4.4^{* * *}$ \\
\hline \multirow{2}{*}{ Egg width, $\mu \mathrm{m}$} & Eg & 23.9 & 27.0 & $25.6 \pm 1.1$ \\
& Ef & 24.5 & 32.4 & $28.4 \pm 2.4^{* *}$ \\
\hline \multirow{2}{*}{ Eggshell thickness, $\mu \mathrm{m}$} & Eg & 2.1 & 2.9 & $2.39 \pm 0.28$ \\
& Ef & 2.9 & 3.6 & $3.22 \pm 0.26^{* * *}$ \\
\hline Inner surface area & Eg & 631.9 & 687.4 & $661 \pm 16$ \\
of the egg, $\mu \mathrm{m}^{2}$ & Ef & 782.4 & 847.3 & $811 \pm 19^{* * *}$ \\
\hline Outer surface area & Eg & 642.0 & 691.1 & $666 \pm 14$ \\
of the egg, $\mu \mathrm{m}^{2}$ & Ef & 785.7 & 855.1 & $819 \pm 19^{* * *}$ \\
\hline
\end{tabular}

Note: Eg - Capillaria eggs extracted from female nematode gonads, Ef - Capillaria eggs extracted from feces of infected chickens; ** $-\mathrm{P}<$ $0.01 ; * * *-\mathrm{P}<0.001$ - compared to the Eg parameter values.

Hence, nematode eggs from the feces of infected chickens are longer by $18.7-25.1 \%(\mathrm{P}<0.001)$ than the eggs extracted from female nematode gonads if either the total egg length or egg length without the egg plugs are analyzed. Simultaneously, the eggs from chicken feces are wider by $10.1 \%(\mathrm{P}<0.01)$, and the eggshell thicker by $25.8 \%(\mathrm{P}<0.001)$ compared to eggs from nematode gonads. Also, the surface areas of $C$. obsignata eggs are very differrent. The eggs from chicken feces have larger outer and inner surface areas, by $18.5 \%$ and $18.6 \%$ respectively $(\mathrm{P}<0.001)$ than the eggs from nematode gonads.

It is established that the embryogenesis of $C$. obsignata at $25^{\circ} \mathrm{C}$ in the laboratory culture occurs in 12 days and can be divided in five provisory stages: zygote (Fig. $6 a$ ), morula or embryo cleavage (Fig. 6b), bean-like embryo (Fig. 6c), tadpole embryo (Fig. 6d), invasive egg (larva, Fig. 6e). The viability of $C$. obsignata eggs is quite high during the embryogenesis ( $90.3 \pm 1.5 \%$, Table 3 ).

At the beginning, $100 \%$ of Capillaria egg culture was at the zygote stage. From the second to the fourth days of culture, the eggs started to change with the cleavage of the embryo and the formation of morula. Thus on day 2, $11.3 \%$ eggs were cleaving, on the 4th day the cleaving embryos reached $66.3 \%$ of all. Later, the number of $C$. obsignata eggs, in which the cleavage process was occurring, decreased to $22.0 \%$ on day 6 , and then to $2.3 \%$ on day 8 . The formation of bean-like embryo occurred in days 4 to 6 .

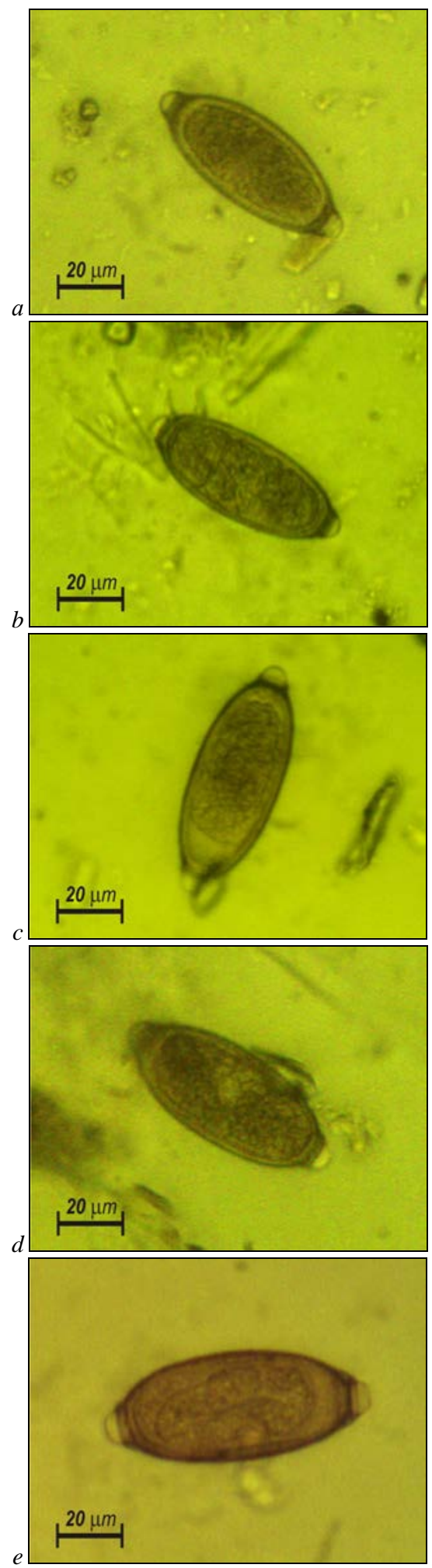

Fig. 6. Stages of embryonic development of Capillaria obsignata: $a$-zygote; $b$ - morula; $c$ - bean-like embryo;

$d$ - tadpole embryo; $e$ - invasive larva

Then, from $15.6 \%$ to $49.6 \%$ of eggs were at this stage of development. The formation of tadpole embryo was recorded at the days 8 to 10 of embryogenesis. At the eighth day, $71.6 \%$ of eggs were at this stage, and on the 10th day this number decreased to 
4.0\%. Larval development occurred gradually since the eighth day of culture when only $7.0 \%$ of eggs were invasive. At the 10th day, $84.3 \%$ of all eggs became invasive. At the 12 th day, the maximum number of invasive eggs was observed, $90.3 \%$. The cessation of development and subsequent death was recorded in $9.6 \%$ of $C$. obsignata eggs. The stages of embryonic development of $C$. obsignata eggs were typical and their morphological changes were supported by meristic parameters (Table 4).

Table 3

The embryonic development of Capillaria obsignata in experimental culture $(\mathrm{M} \pm \mathrm{SD}, \mathrm{n}=100)$

\begin{tabular}{|c|c|c|c|c|c|c|}
\hline \multirow[b]{2}{*}{ Day of culture } & \multicolumn{5}{|c|}{ Stages of egg development, \% } & \multirow{2}{*}{$\begin{array}{c}\text { Cessation } \\
\text { of development }\end{array}$} \\
\hline & zygote & $\begin{array}{c}\text { morula } \\
\text { (cleavage of embryo) }\end{array}$ & bean-like embryo & $\begin{array}{l}\text { evelopment of } \\
\text { tadpole embryo }\end{array}$ & larva & \\
\hline Before culturing & 100 & - & - & - & - & - \\
\hline 2 & $88.66 \pm 2.52$ & $11.33 \pm 2.52$ & - & - & - & - \\
\hline 4 & $18.00 \pm 2.00$ & $66.33 \pm 3.79$ & $15.66 \pm 2.08$ & - & - & - \\
\hline 6 & $9.66 \pm 1.53$ & $22.00 \pm 2.00$ & $49.66 \pm 2.51$ & $18.67 \pm 3.05$ & - & - \\
\hline 8 & - & $2.33 \pm 1.53$ & $9.33 \pm 2.51$ & $71.66 \pm 2.08$ & $7.00 \pm 3.61$ & $9.66 \pm 1.53$ \\
\hline 10 & - & - & $2.00 \pm 1.00$ & $4.00 \pm 1.00$ & $84.33 \pm 3.05$ & $9.66 \pm 1.53$ \\
\hline 12 & - & - & - & - & $90.33 \pm 1.53$ & $9.66 \pm 1.53$ \\
\hline
\end{tabular}

Table 4

Meristic parameters of Capillaria obsignata embryonic development in experimental culture $(\mathrm{M} \pm \mathrm{SD}, \mathrm{n}=10)$

\begin{tabular}{|c|c|c|c|c|c|c|c|}
\hline \multirow{2}{*}{ Parameters, $\mu \mathrm{m}$} & \multirow{2}{*}{$\begin{array}{c}\text { Before } \\
\text { cultivation }\end{array}$} & \multicolumn{6}{|c|}{ Day of culture } \\
\hline & & 2 & 4 & 6 & 8 & 10 & 12 \\
\hline Length & $65.34 \pm 5.12$ & $67.88 \pm 4.91$ & $69.09 \pm 5.21$ & $71.08 \pm 6.28 *$ & $72.27 \pm 4.32 * *$ & $72.66 \pm 3.69 * *$ & $73.57 \pm 7.53^{* *}$ \\
\hline Width & $28.42 \pm 2.35$ & $28.87 \pm 2.05$ & $29.14 \pm 2.02$ & $29.24 \pm 2.97$ & $29.57 \pm 2.57$ & $30.61 \pm 1.67 *$ & $30.72 \pm 2.56^{*}$ \\
\hline Eggshell thickness & $3.14 \pm 0.24$ & $3.12 \pm 0.25$ & $3.11 \pm 0.25$ & $3.09 \pm 0.26$ & $3.09 \pm 0.29$ & $3.08 \pm 0.29$ & $3.08 \pm 0.28$ \\
\hline
\end{tabular}

Note: $*-\mathrm{P}<0.05, * *-\mathrm{P}<0.01$ compared to parameters before cultivation.

Thus, in embryonic development of bean-like embryo, the egg length significantly increased, starting at the sixth day of cultivation, by $4.5 \%(\mathrm{P}<0.05)$. At the eighth day, the embryogenesis was at the stage of tadpole embryo, and its length increased by $6.1 \%(\mathrm{P}<0.05)$ compared to before cultivation. At the 10th and 12th days, the length of invasive larva increased still by $10.1 \%$ and $11.2 \%$ ( $<$ 0.01 ) respectively. The egg width began to change at the larval formation stage, and increased by $7.5 \%(\mathrm{P}<0.05)$ at the 12 th day compared to that at the zygote stage. The eggshell thickness decreased but insignificantly. Thus, $C$. obsignata eggs differ depending on the stage of embryogenesis and the initial substrate. These specifics should be considered in species identification.

\section{Discussion}

The population of $C$. obsignata is well adapted to parasitizing chickens (Gallus gallus dom.) in the climatic conditions of central Ukraine (Poltava and Kiev regions), which is confirmed by the population statistics. The abundance index is 3.4 , the intensity of capillariasis infection is 317 specimens in several cases. It is well known that $C$. obsignata is adapted to parasitizing domestic, wild, and synanthropic birds. The occurrence of cross infection means that this nematode is not a species-specific parasite (Levine, 1938; Wakelin, 1965; Gürler et al., 2012). This factor facilitates the wide distribution of $C$. obsignata in many countries, as confirmed by many studies (Permin, 1999; Mukaratirwa and Khumalo, 2010; Kaufmann et al., 2011; Yazwinski et al., 2013). In Ukraine, there are a few studies of the abundance of $C$. obsignata in birds, revealing the significant infection of chickens, especially floor-reared (extensiveness of infection up to 100\%) in Dnepropetrovsk region (Zaikina and Marshalkina, 2015).

We found out that the studied population of $C$. obsignata is represented mostly by females (88.8\%), and 3.5\% of studied birds had no male parasites. This supports previous findings (D’ávila et al., 2012) which also testifies to the roundworm's biological adaptation to certain conditions and interaction with the host. That is, the females live longer to provide successful reproduction, and the males leave the host after fertilization.

New data are found on the morphometric characteristics of adult and embryonic stages of $C$. obsignata development. The species has been studied for a significant period, and there are widely known identification keys (Skrjabin, 1957; Ivashkin et al., 1971). However, the keys do not incorporate the specific variability which can affect both the morphological and meristic parameters of these roundworms. The average length of mature females is $14.75 \pm 0.82 \mathrm{~mm}$, their width in various body parts ranges from $9.43 \pm 0.53$ to $57.09 \pm$ $2,65 \mu \mathrm{m}$. These values are lower in males by $10.2-23.7 \%$, their length is $11.25 \pm 0.63 \mathrm{~mm}$, their width is $8.47 \pm 0.56$ to $47.27 \pm$ $1,94 \mu \mathrm{m}$. However, several sources give the length of $C$. obsignata females from 9.1 to $40.0 \mathrm{~mm}$, and the length of male roundworms from 5.83 to 18.6 mm (Kajerová and Baruš, 2005; D’Ávila et al., 2017). The mature females and males in our study were unequal by their body lengths ( +13.5 to $16.0 \mathrm{~mm}, \curvearrowright 10.5$ to $12.6 \mathrm{~mm}$ ). This, too, confirms their adaptive morphological variability, which causes the difference in the nematode sizes. Among other typical meristic parameters, there is the length of the pseudobursa $(35.54 \pm 1,42 \mu \mathrm{m})$, distance between the rays of the pseudobursa $(13.57 \pm 0.74 \mu \mathrm{m})$, and the lengths and widths of the spicule and spicule sheath at the distal and proximal ends. All this should be taken into account in species identification.

In most of the identification keys, the slit vulva and insignificant vulval lip are thought to be typical for $C$. obsignata females. We, however, must point out that the size and height of this vulval lip are very variable $(2.0$ to $7.2 \mu \mathrm{m})$, thus making difficult the species identification. Hence, the meristic characteristics of females should also be considered, such as the distance from the end of esophagus to the vulva $(82.65 \pm 4,63 \mu \mathrm{m})$ and length of the vagina $(173.66 \pm 9,81 \mu \mathrm{m})$. Additionally, body width in the anus area, in the area of the posterior esophagus $(57.09 \pm 2,65 \mu \mathrm{m})$, and at the anterior end of body $(9.43 \pm 0.53 \mu \mathrm{m})$ can be used to identify female roundworms.

We established that the parameters of $C$. obsignata eggs extracted from feces of the infected chickens are significantly larger than those of eggs obtained from the gonads of female nematodes. Additional indicators (shell thickness, inner and outer egg surfaces) are also proposed, to complement the already existing data. Thus, the nematode eggs isolated from chickens are longer by $18.7 \%$ to $25.1 \%$ $(\mathrm{P}<0.001)$ and wider by $10.1 \%(\mathrm{P}<0.01)$ compared to eggs isolated from gonads. At the same time, the shell thickness of eggs isolated from the chicken feces, and their inner and outer surfaces are also higher by $25.8 \%, 18.5 \%$ and $18.6 \%$ ( $<$ < 0.001), respectively. Such changes testify to the growth and development of eggs during their migration from the small intestine, where they are excreted by the female, to the external environment along with the avian feces.

We obtained new data on the embryogenesis of $C$. obsignata in laboratory conditions. At $25{ }^{\circ} \mathrm{C}$, the roundworm's eggs develop to 
the invasive stage in 12 days with high viability (up to $90.3 \pm 1,5 \%$ ), which contributes to their population growth, rapid cross infection in birds, and survivability of the nematode eggs in the external environment. For the first time, five embryonic developmental stages of $C$. obsignata are identified, with clear morphological and meristic characteristics, and a stage-by-stage transition from one stage to the next. The first stage, formation of the zygote, morphologically differs by the homogeneous filling of the egg cavity, and is observed in the first two days of cultivation (100.0-88.7\%). The second stage, the cleavage of the zygote into morula, is characterized by the formation of unequal blastomeres in the egg cavity during the 4th to 6th days of embryogenesis (66.3-22.0\%). The third and fourth stages (bean-like and tadpole embryos) are recognizable by the formation of an embryo shaped like a bean or a tadpole in the egg cavity. These changes were detected mainly on the 6th and 8th days (to $49.6 \%$ and $71.6 \%$ ). The fifth and final stage is characterized by the formation of a mobile larva in the egg cavity, which indicated its viability. On the 10th to 12th days of cultivation, the number of invasive eggs was within $84.3 \%$ to $90.3 \%$. Such development of $C$. obsignata eggs was also confirmed by meristic parameters (length and width, increased by $11.2 \%, \mathrm{P}<0.01$ and $7.5 \%$, $\mathrm{P}<0.05$, respectively). We added to the already existing data on the embryonic development of $C$. obsignata, which previously have distinguished only three stages of egg development for this species: eggs without embryo, eggs with a mobile embryo, and invasive larva (Tiersch et al., 2013). Meristic parameters of eggs undergoing embryogenesis are shown for the first time.

\section{Conclusion}

The C. obsignata nematodes, which parasitize chickens, are highly abundant in the central Ukraine (the abundance index was up to 3.4). Female roundworms dominated in the collected material (88.8\%). The new species-identifying characters of adult $C$. obsignata are morphometric. The mature males are identified by the shape, length and width of pseudobursa; distance between its rays; the shape and width of the spicule and spicule sheath in its proximal and distal parts. The females are distinguished by the size of the cuticle vulval lip, which is very variable; the distance between the esophagus end to the vulva; vagina length.

The meristic parameters of embryonic stages of $C$. obsignata are quite variable and depend on the sampled substrate and the stage of development. To facilitate species identification, it is suggested to consider not only the length and width of the eggs, but also their inner and outer surface areas and eggshell thickness. In laboratory conditions, the embryogenesis of $C$. obsignata occurs in five stages: zygote, morula, bean-like embryo, tadpole embryo, invasive larva. They have significant morphological and meristic specifics. The experimental embryogenesis of $C$. obsignata occurs in 12 days, and the survival is $90.3 \%$.

\section{Acknowlegements}

The authors are thankful to Dr. Y. I. Kuzmin (Kyiv, Ukraine) for his helpful suggestions.

\section{References}

D’ávila, S., Bessa, E. C. A., \& Rodrigues, M. L .A. (2017). Estudo morfométrico e aspectos taxonômicos de Baruscapillaria obsignata (Nematoda, Capillariidae), parasito de Columba livia (Aves, Columbidae). Revista Brasileira de Zoociências, 18(2), 35-44.

D’ávila, S., Bessa, E. C. A., Souza-Lima, S., \& Rodrigues, M. L. A. (2012). Biased sex ratio and niche restriction in Baruscapillaria obsignata (Madsen 1945) (Nematoda, Capillariidae) from Columba livia (Aves, Columbidae). Journal of Helminthology, 86(4), 401-405.

Gagarin, V. G. (1971). Znachenie vidovyh i rodovyh kriteriev na primere kapilljariid [The significance of specific and generic criteria on the example of Capillariidae]. Helminthological studies in Kyrgyzstan. Ilim, Frunze (in Russian).
Gürler, A. T., Bölükbaş, C. S., Pekmezci, G. Z., Umur, Ş., \& Açıı, M. (2012). Samsun'da Sülünlerde (Phasianus colchicus) Nekropsi ve Dışkı Bakısında Saptanan Helmintler. Türkiye Parazitoloji Dergisi, 36, 222-722.

Hassouni, T., \& Belghyti, D. (2006). Distribution of gastrointestinal helminths in chicken farms in the Gharb region - Morocco. Parasitology Research, 99(2), 181-183.

Ivashkin, V. M., Kontrimavichus, V. L., \& Nazarova, N. S. (1971). Metody sbora i izuchenija gel'mintov nazemnyh pozvonochnyh [Methods for collection and study of terrestrial mammals' helminthes.]. Nauka, Moscow (in Russian).

Kajerová, V., \& Baruš, V. (2005). Psittacine birds (Aves: Psittaciformes) as new hosts of Baruscapillaria obsignata (Nematoda: Capillariidae). Acta Veterinaria Brno, 74, 571-574.

Kaufmann, F., Daş, G., Sohnrey, B., \& Gauly, M. (2011). Helminth infections in laying hens kept in organic free range systems in Germany. Livestock Science, 141(2-3), 182-187.

Lapach, S. N., Chubenko, A. V., \& Babich, P. N. (2001). Statisticheskie metody v mediko-biologicheskih issledovanijah s ispol'zovaniem Excel [Statistical methods in medical and biological research using Excel]. Morion, Kyiv (in Russian).

Levine, P. P. (1938). Infection of the chicken with Capillaria columbae (Rud.). Joumal of Parasitology, 24(1), 45-52.

Lomakin, V. V., \& Romashov, B. V. (1987). Morfolgo-taksonomicheskij analiz i filogeneticheskie otnoshenija nematod semejstva Capillariidae Railliet, 1915 [Morphological-taxonomic analysis and phylogenetic relationships of nematodes of the family Capillariidae Railliet, 1915]. Morphology, Taxonomy and Ecology of Helminthes of Plants and Animals, 35, 87-95 (in Russian).

Moravec, F., \& Muzzall, P. M. (2009). New species of freitas Capillaria (Nematoda: Capillariidae) from the intestine of Cottus caeruleomentum (Teleostei: Cottidae) in Maryland. Journal of Parasitology, 95(4), 987-990.

Moravec, F., Scholz, T., \& Našincová, V. (1994). The systematic status of Trichosoma carbonis Rudolphi, 1819 and a description of Baruscapillaria rudolphii n. sp. (Nematoda: Capillariidae), an intestinal parasite of cormorants. Systematic Parasitology, 28(2), 153-158.

Mukaratirwa, S., \& Khumalo, M. P. (2010). Prevalence of helminth parasites in free-range chickens from selected rural communities in KwaZulu-Natal province of South Africa. Journal of the South African Veterinary Association, 81(2), 97-101.

Mukaratirwa, S., Hove, T., Esmann, J. B., Hoj, C. J., Permin, A., \& Nansen, P. (2001). A survey of parasitic nematode infections of chickens in rural Zimbabwe. Onderstepoort Journal of Veterinary Research, 68(3), 183-186.

Nasirov, A. M. (1981). Tonkoe stroenie polovoj sistemy samok Capillaria obsignata Madsen, 1945 [The fine structure of female reproductive system of Capillaria obsignata Madsen, 1945]. Proceedings of the National Academy of Sciences of Azerbaijan, 5, 76-77 (in Russian).

Paramonov, A. A. (1957). O principah taksonomicheskoj differencirovki v nematologii [On the principles of taxonomic differentiation in nematology]. Russian Journal of Zoology, 34(5), 641-653 (in Russian).

Park, S.-I., \& Shin, S. S. (2010). Concurrent Capillaria and Heterakis infections in zoo rock partridges, Alectoris graeca. Korean Journal of Parasitology, 48(3), 253-257.

Pasechnik, V. E. (2013). Kapilljariidy ptic i ih jepizooticheskoe znachenie v Moskovskom regione [Bird capillariases and their epizootic importance in the Moscow region]. Theory and Practice of the Struggle Against Parasitic Diseases, 14, 298-300 (in Russian).

Petrochenko, V. I., \& Kotelnikov, G. A. (1976). Gel'mintozy ptic [Helminthic diseases of birds]. Kolos, Moscow (in Russian).

Ripolovskyi, O. I., \& Yuskiv, I. D. (2010). Dyplostomozy koropa v nahulnykh stavakh Pivnichno-Zakhidnoho Peredkarpattia [Diplostomoses of carp in the ponds of the North-Western Prykarpathia]. Scientific Bulletin of Lviv National University of Veterinary Medicine and Biotechnologies named after S. Z. Gzhytskyj, 12(3), 197-205 (in Ukrainian).

Romashov, B. V. (1985). Morfologicheskie osobennosti skorlupy jaic kapilljariid (Nematoda, Capillariidae) [The morphological specifics of eggshell in Capillariidae (Nematoda, Capillariidae)]. Parasitology, 19(5), 399-402 (in Russian).

Schou, T. W., Permin, A., Juul-Madsen, H. R., \& Sǿrensen, P. (2007). Gastrointestinal helminths in indigenous and exotic chickens in Vietnam: Association of the intensity of infection with the Major Histocompatibility Complex. Parasitology, 134, 561-573.

Skrjabin, K. I. (1928). Metod polnyh gel'mintologicheskih vskrytij pozvonochnyh, vkljuchaja cheloveka [The method of complete helminthological autopsy of vertebrates, including humans]. First Moscow State University, Moscow (in Russian).

Skrjabin, K. I., Shikhobalova, N. P., \& Orlov, I. V. (1957). Trihocefalidy i kapilljariidy zhivotnyh i cheloveka i vyzyvaemye imi zabolevanija [Trichocephalids and capillariids of animals and man and the diseases caused by them. The essentials of nematodology]. Academy of Sciences of the USSR, Moscow (in Russian). 
Tamaru, M., Yamaki, S., Jimenez, L. A., \& Sato, H. (2015). Morphological and molecular genetic characterization of three Capillaria spp. (Capillaria anatis, Capillaria pudendotecta, and Capillaria madseni) and Baruscapillaria obsignata (Nematoda: Trichuridae: Capillariinae) in avians. Parasitology Research, 114(11), 4011-4022.

Tanveer, S., Ahad, S., \& Chishti, M. Z. (2015). Morphological characterization of nematodes of the genera Capillaria, Acuaria, Amidostomum, Streptocara, Heterakis, and Ascaridia isolated from intestine and gizzard of domestic birds from different regions of the temperate Kashmir valley. Journal of Parasitic Diseases, 39(4), 745-760.

Tiersch, K. M., Daș, G., Samson-Himmelstjerna, G. V., \& Gauly, M. (2013). The role of culture media on embryonation and subsequent infectivity of Capillaria obsignata eggs. Parasitology Research, 112(1), 357-364.
Timi, J. T., Rossin, M. A., \& Lanfranchi, A. L. (2006). A new species of Capillaria (Nematoda: Capillariidae) parasitizing conger Orbignianus (Pisces: Congridae) from Argentina. Journal of Parasitology, 92(3), 628-630.

Wakelin, D. (1965). Experimental studies on the biology of Capillaria obsignata Madsen, 1945, a nematode parasite of the domestic fowl. Journal of Helminthology, 39(4), 399-412.

Wakelin, D. (1966). The genus Capillaria Zeder, 1800 (Nematoda) in British passerine birds. Parasitology, 56(1), 161-170.

Wehr, E. E. (1939). Studies on the development of the pigeon capillarid, Capillaria columbae. United States Department of Agriculture, Washington.

Yazwinski, T., Tucker, C., Wray, E., Jones, L., Johnson, Z., Steinlage, S., \& Bridges, J. (2013). A survey on the incidence and magnitude of intestinal helminthiasis in broiler breeders originating from the southeastern United States. Journal of Applied Poultry Research, 22(4), 942-947. 